\title{
Iconografía comercial del deporte
}

\author{
Raúl EgUIZÁBAL MAZA \\ Universidad Complutense de Madrid \\ r.eguizabal@ccinf.ucm.es
}

Recibido: 5 de septiembre de 2012.

Aceptado: 1 de octubre de 2012.

\begin{abstract}
Resumen
El objetivo de este artículo es el estudio de las relaciones entre deporte y publicidad, a través de las imágenes de la publicidad gráfica producida en España, y empleando con este fin el método iconológico. Para ello se establecen tres tipos de vínculos que corresponden a tres diferentes períodos históricos. Y se estudian las imágenes tanto en su relación con otras anteriores o contemporáneas a la que sirve de estudio, como mediante un proceso de contextualización; estudiando las imágenes a la luz de la relación con los textos que las acompañan (el registro verbal del anuncio) y con la situación (comunicativa y sociocultural) en que se producen.
\end{abstract}

Palabras clave: Publicidad; imagen; deporte; historia; iconografía.

\section{Commercial iconography of sport}

\begin{abstract}
The aim of this article is the study of the relationships between sport and advertising through the images of advertising graphics, using for this purpose the iconological method. Three types of links that correspond to three different historical periods are set to do so. And images are studied both in their relationship with other prior or contemporaneous which serves as a study, and through a process of contextualisation; studying the images in the light of the relationship with the texts that accompany them (the verbal record of the announcement) and with the situation (communicative and sociocultural) as they occur.
\end{abstract}

Key words: Iconography; history; sport; advertising; image.

\section{Referencia normalizada}

Eguizabal Maza, R. (2012). Iconografía comercial del deporte. Historia y Comunicación Social, Vol. 17, páginas 359-380.

Sumario: 1. Introducción. 2. Objetivos y metodología. 3. La publicidad del deporte. 4. El deporte en la publicidad. 5. El deporte como publicidad. 6. Bibliografía.

\section{Introducción}

El deporte moderno surge en el siglo XIX más vinculado a la higiene, la formación y la salud, que al espectáculo, tal y como se entiende hoy día, o que a un valor conmemorativo y religioso como parece que se entendía en la antigüedad. De hecho, el término castellano "deporte", que se remonta al siglo XV, es resucitado en ese siglo para traducir el término inglés sport. Y es que, en gran medida, Inglaterra -el país más industrializado y más modernizado por la época- constituye la cuna del 
deporte moderno. Hasta ese momento el sport era más bien un modo de vida, el modo de vida de las clases acomodadas, de los gentleman: una mezcla de buenos modales, elegancia, cortesía y compostura.

Gracias a las acciones del pedagogo e historiador Thomas Arnold (1795-1842), quien lo introdujo en la enseñanza británica, el deporte dejó de ser un simple recreo o diversión para convertirse en herramienta de la pedagogía moderna.

Entendido así, el deporte constituía un instrumento para educar en ciertos valores como el sentido de la responsabilidad, la iniciativa y la lealtad. Arnold fue headmaster del colegio de Rugby (donde se creó el juego que lleva ese nombre), desde el que se propuso una reforma de las costumbres de la juventud y donde empezó a concebirse la idea del fair play en sintonía con su pensamiento pedagógico.

Así mismo, los primeros periódicos deportivos surgieron en Inglaterra en la primera mitad de ese mismo siglo: Sporting Life (1821) y Bell's Life (1838); ambos diarios especializados en carreras de caballos.

El hecho es que la vida burguesa pronto fue reconocida como poco apropiada para la salud, ciudades contaminadas por el humo del carbón, con deficiencias en los sistemas de alcantarillado y agua corriente, y crecientes concentraciones de población debidas a las migraciones desde las zonas rurales y campesinas a las industriales y urbanas. Desde luego que la parte más sombría del tema se situaba en los extrarradios, en los que las condiciones higiénicas y el amontonamiento de la población (junto a otros elementos como el alcoholismo y la deficiente alimentación) convertían los suburbios en reductos de miseria.

Los beneficios del deporte se situaban, por entonces, muy lejos de la población obrera, y estaban más bien vinculados a ciertas prácticas aristocráticas, como la esgrima, la caza o la equitación, próximas al arte de la guerra, así como a la naciente costumbre del veraneo que incluía, de la misma forma, diversas prácticas deportivas: natación, remo, tenis. Es por eso, también, que algunos de los primeros anuncios en los que aparece representado el deporte están vinculados a carteles turísticos, como por ejemplo los deportes de nieve y la publicidad turística suiza.

El mismo escenario que vio nacer el deporte moderno es, en definitiva, el que dio lugar al nacimiento de la publicidad: industrialización, burguesía, formas incipientes de consumo y de ocio. La publicidad no es sino la tecnificación o racionalización de una actividad, el anuncio, que venía existiendo desde antiguo aunque de una forma coyuntural y asistemática. De la misma forma que el deporte moderno suponía la puesta en práctica de una serie de reglas dentro de un juego, y la tecnificación de lo que hasta entonces eran meros ejercicios gimnásticos, la publicidad elaboró, asimismo por entonces, una serie de reglas de funcionamiento, de organismos e instituciones que contribuyeron a definirla tal y como hoy la conocemos.

Tanto el deporte como la publicidad consiguieron incorporar algunos de los significados (de los mitos) más esenciales de la vida moderna: la competencia como el escenario idóneo para su desarrollo, la superación personal, la autorrealización, la búsqueda de la armonía como principio rector de la convivencia entre las naciones o de la convivencia entre las empresas competidoras. También en el terreno empresarial se impuso el fair play, y a una competencia feroz propia del "capitalismo 
salvaje", resuelta muchas veces mediante sabotajes, huelgas inducidas, guerras irracionales de precios, le sustituyó la competencia "civilizada" en los terrenos de la distribución y la promoción de las mercancías.

El programa de tecnificación de las diversas actividades, a lo largo del siglo XIX, supuso el impulso modernizador tanto de la publicidad (mediante las herramientas que le aportaban la psicología y el estudio de los mercados) como del deporte (con los avances en la medición cronométrica y la cuantificación estadística que permitieron la fijación del record como elemento esencial de su práctica moderna). En verdad, el deporte suponía la incorporación de los principios de la producción moderna: la libre competencia, la productividad y el rendimiento máximo.

\section{Objetivos y metodología}

El objetivo de este artículo es, por tanto, el estudio de esos vínculos entre deporte y publicidad, ver la forma en que la publicidad ha utilizado al deporte, y el deporte a la publicidad a lo largo del tiempo. Para ello estableceremos tres etapas que suponen diversas formas de relación, entendiendo que éstas son acumulativas, es decir: un nuevo tipo de vínculo no ha hecho desaparecer el anterior, sino que se ha sumado a él.

Nos moveremos para ello, en el terreno de la iconología, es decir en el de la interpretación de las imágenes, en parte a la manera de la iconología clásica, vinculando unas imágenes con otras anteriores o contemporáneas a la que sirve de estudio; pero sobre todo mediante un proceso de contextualización: esto es, estudiando las imágenes en su relación con los textos que las acompañan (el registro verbal del anuncio) y con la situación (comunicativa y sociocultural) en que se producen.

La ventaja del método iconológico, para mis objetivos, es, a mi entender, su contrastada validez para trabajar sobre un contexto histórico, para buscar significados a las obras en una dimensión temporal. Para ello fija su atención en los temas y los símbolos, pero también encuentra el significado en los aspectos formales. Un buen ejemplo de ello sería, precisamente, el modernismo, un estilo dominante en la publicidad del novecientos en el que los aspectos formales (las líneas sinuosas, los motivos vegetales, ...) no eran un adorno inútil sino que representaban una ideología: la lucha de la belleza y de la naturaleza contra el mundo de la fealdad industrial.

El anuncio forma parte de la cultura industrial y la cultura es "la fábrica del significado con arreglo al cual los seres humanos interpretan su experiencia y guían sus acciones" (Geertz 1973: 144-145 en M. Harris 2004: 17).

La interpretación, incluso rechazando la posibilidad de un acceso directo, intuitivo, a los objetos, en beneficio de una postura teóricamente comprometida deja abierta la puerta de la subjetividad. En el paradigma tradicional, la historia es objetiva, y la tarea del historiador era ofrecer los hechos "tal y como habían sido realmente". También la ciencia estaba embebida del mismo tipo de pretensiones: "la postura behaviorista de los años veinte tendía a rechazar la legitimidad científica de todas las categorías subjetivas, de todos los conceptos de "significado"... mientras 
que hoy se formula en términos de motivos, metas, símbolos, significados, medios y fines, y parámetros similares" (M. Harris 2004: 40).

Estas posturas se consideran hoy, en general, quiméricas. No es que la ciencia nos libre de todo error o de todo fraude subjetivo, es que sus principios epistemológicos son los que hoy por hoy nos garantizan una mayor probabilidad de librarnos de errores, falsedades o fraudes subjetivos. Tampoco la historiografía nos garantiza la verdad ni podemos evitar mirar el pasado desde una perspectiva particular: "El relativismo cultural se aplica, como es obvio, tanto a la historiografía misma como a lo que se denominan sus objetos" (Burke 2003: 19). Frente al determinismo del paradigma tradicional, el relativismo cultural del actual.

El interés por el significado es también lo que motiva el que la nueva historia se centre en el análisis de estructuras, más que en la narración de acontecimientos como ocurría en el pasado. La historia del arte no es la historia de los artistas, sino la del arte como sistema. La historia de la publicidad no es la de sus artífices, su origen reside en su formación como sistema (y en la aparición de unas "reglas del juego") y su análisis en el de su estructura.

El método iconológico supuso una reacción contra los análisis formales de las imágenes preocupados por temas como el color, la composición, etc. Desde el grupo de Hamburgo -comandado por Aby Warburg, y al que pertenecieron entre otros, el iconólogo Panofsky, el filósofo Ernest Cassirer y el historiador del arte E. H. Gombrich (autor de Aby Warburg. Una biografía intelectual, 1970)- se defendía una investigación de las imágenes centrada en los temas y en los símbolos.

En esta línea, Panofsky propuso una lectura de las imágenes en tres niveles: un nivel preiconográfico de identificación de las figuras representadas en las imágenes (objetos naturales y artificiales, animales y personas) y de las situaciones (banquetes, fiestas, desfiles, etc.); un segundo nivel, de análisis iconográfico en el que se reconocen dichos elementos con relación a una cultura (reconocemos que ese personaje es Hermes, dios del comercio, o que esa es una comida de Navidad o es una recreación de la Última Cena), se ponen en evidencia los "significados convencionales", en los que dichas convenciones son históricas y culturales. El tercer nivel corresponde a la interpretación iconológica, que extrae la forma en que se refleja en la imagen una sociedad, una clase social, un país, una ideología o unas creencias.

Hay otras interpretaciones del método iconológico o iconográfico, pero básicamente coinciden en el contexto histórico y en la vinculación de la imagen con el resto de los fenómenos culturales, siendo imprescindible para interpretar un mensaje estar familiarizado con los códigos culturales. Incluso aquello que parece obvio, "de cajón" o de "sentido común", suele responder también a la existencia de un sistema cultural.

Si el método resulta valioso para interpretar obras de arte, mucho más adecuado parece todavía para interpretar imágenes publicitarias.

Primero, porque la importancia de los aspectos formales en la publicidad es mucho menor que en el arte (todo, incluido los aspectos plásticos, responde a una funcionalidad en la comunicación publicitaria).

Segundo, porque la presencia de rasgos sociales y culturales en los mensajes 
publicitarios es consciente y deliberada: comparemos un paisaje americano del siglo XIX y un anuncio de Marlboro con su característico paisaje de película del Oeste, ambos dan una cierta impresión de desolación que en la pintura quizá está inconscientemente guiada por las convenciones de la época, pero que en el anuncio es con certeza una sensación buscada para trasmitir ciertos significados de libertad, de regreso a la naturaleza viva, de pureza de la mercancía y de "este producto es profundamente americano".

Tercero, porque ha sido codificado con el fin de ser decodificado de cierta manera, y por tanto es mucho más probable que así mismo nuestra lectura esté en el camino correcto.

Cuarto, porque tras el mensaje publicitario existe un programa (una estrategia, se dice en la terminología) de la que el mensaje es su manifestación. También en la pintura tradicional existía, al parecer, un "consejero humanista" que proponía el programa iconográfico que ejecutaban los artistas, pero en la historia del arte lo que se destacaba era el papel del artista en la obra; además ni siquiera podemos estar seguros de que ese programador existiese en todos los casos.

Debido a las inevitables restricciones de espacio, nuestro análisis estará limitado en tres sentidos: tan sólo contemplaremos el caso de la publicidad gráfica producida para el mercado español, prescindiremos de un tratamiento extensivo del universo documental eligiendo los casos más representativos tras una "lectura flotante" de los mensajes, nos centraremos en la interpretación (desechando prolijas descripciones literales) de aquellos elementos manifiestamente vinculados al objetivo de este trabajo.

\section{La publicidad del deporte}

Los primeros anuncios españoles, que tengamos constancia, en los que se trata el tema del deporte son un grupo de carteles que anuncian carreras de caballos en Sevilla y Madrid, más un cartel turístico del Gran Casino de San Sebastián en el que aparece una referencia iconográfica al deporte de la esgrima y otra al deporte del tiro.

No es casualidad que estos deportes, hípica, esgrima, tiro, hayan estado vinculados a las costumbres aristocráticas, costumbres que la gran burguesía procuraba imitar, en aquellos momentos, con más o menos acierto. En este sentido los carteles madrileños incluyen la referencia "Bajo la dirección de la Sociedad de Fomento Caballar de la que es presidente honorario S. M. El Rey". La figura del rey era capaz todavía de envolver en un aura de prestigio cualquier actividad, por prosaica que fuese.

Los carteles hípicos, ocho en total, se extienden de 1876 a 1885 . Uno de ellos es totalmente tipográfico, el resto incluye viñetas xilográficas o litográficas, según los casos. Todas las imágenes representan una misma escena: los caballos a galope, montados por jinetes vestidos con el clásico aditamento del "jockey" (Fig. 1). Las imágenes se repiten de uno a otro cartel. En total aparecen tres viñetas diferentes, siendo de mayor tamaño y mejor factura la de los carteles sevillanos. 


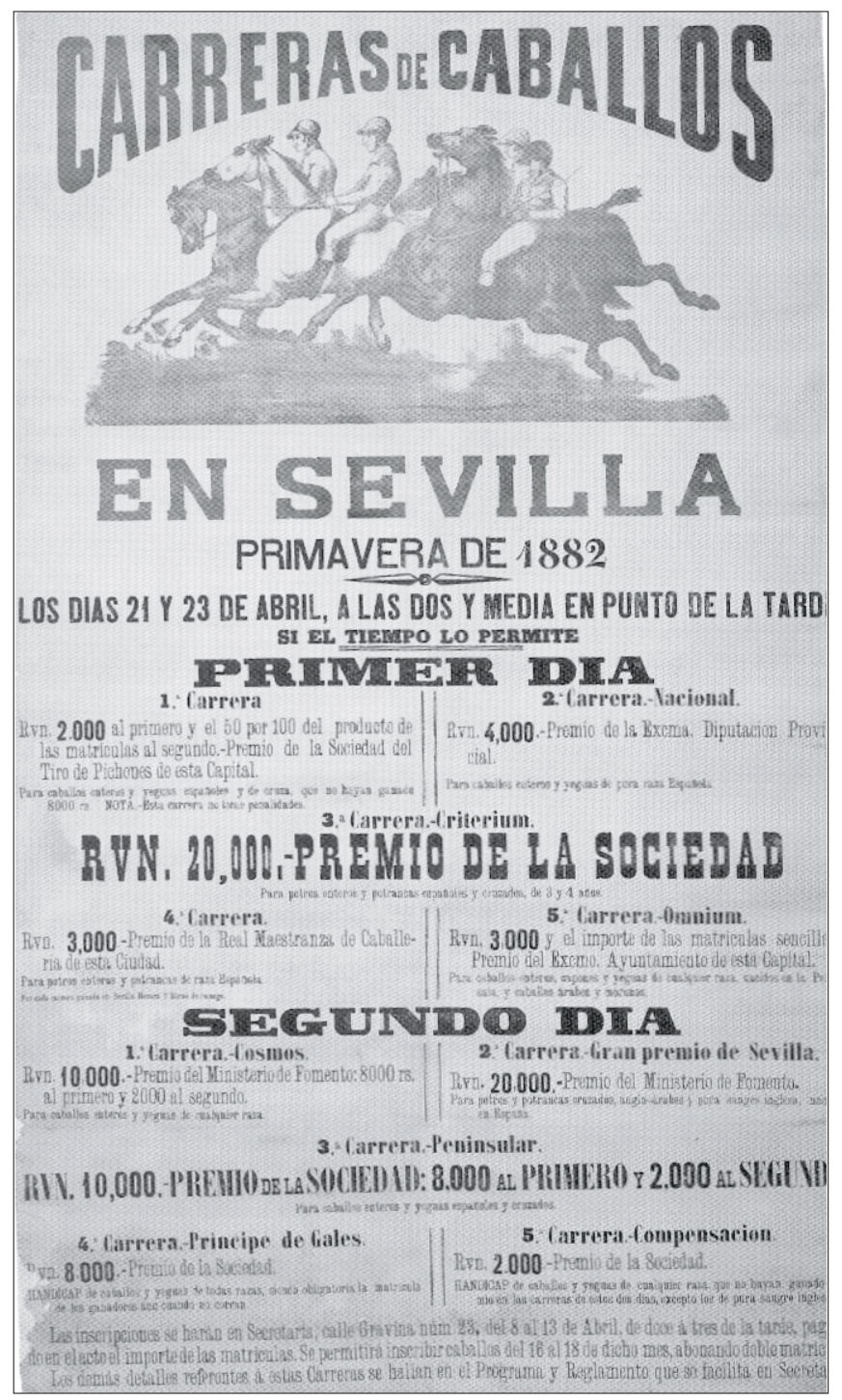

Fig. 1. Sociedad de Fomento de la Cría Caballar de España. Anónimo. 1882

Ahora bien, ¿qué significaba por entonces el deporte de la hípica? ¿Por qué las carreras de caballos justificaban por sí mismas la existencia de estos carteles (y de otros que no han llegado hasta nosotros)?

A pesar de que la máquina iba sustituyendo en muchos casos a la fuerza animal, el caballo constituía todavía un elemento cotidiano en las calles, e imprescindible en los ejércitos. Tirando o no de vehículos, mulas y caballos (más de los primeros que de los segundos) pueblan todavía las vías en la segunda mitad del siglo. No sería hasta 1885, con el invento de la cadena, que la bicicleta empezase a popularizarse en algunos países y a desplazar a monturas más tradicionales. El anuncio más antiguo que se conserva en España, referido al ciclismo, es un cartel de finales de siglo (hacia 1897) de "Carreras de velocípedos en Granada". Se conoce que el nombre de bicicleta todavía no estaba extendido y se mantenía la primitiva denominación de velocípedo, aunque lo que aparecen representadas son bicis con su correspondiente cadena.

Paulatinamente, el caballo se iría arrinconando, reservado para los desfiles y como artículo de lujo y símbolo social en los carruajes. Las carreras representaban el intento de preservar el lado épico y decorativo del caballo. El caballo oponía su belleza y nobleza a la fealdad y plebeyez de las máquinas.

No obstante, la simpatía hacia las carreras de caballos, que es costumbre importada de Inglaterra, se reduce a determinados círculos sociales. La ciudadanía sigue prefiriendo el espectáculo de los toros, tal y como nos relata un cronista de la época: "Salvo un núcleo de aristócratas y militares, no se aficionan los madrileños a las carreras de caballos. No entienden las peripecias y lances de un hipódromo, ni aprecian la emoción de las apuestas. '¡Qué buen día de toros!' se exclama en un día de carreras. Y el pueblo silba a los jockeys que se quedan rezagados" (A. de Figueroa: 1942: 152).

Los aficionados a los caballos, bien que escasos, parecían en realidad más inte- 
resados por el ambiente social del hipódromo (las apuestas, las cocottes y el roce social) que por el deporte en sí mismo. Pero es también todo un símbolo de los tiempos cambiantes el hecho de que el caballo quede reducido a los desfiles, a la ostentación o al deporte, y sirva más como signo de distinción que como auténtico medio de locomoción.

El cartel del Gran Casino de San Sebastián es de1887 (Fig. 2). Se trata de un gran cartel cromolitográfico $(238 \times 87 \mathrm{~cm}$.) como empezaba a ser habitual por esas fechas. Entre otros atractivos vinculados al ocio y la salud -baños en el mar, hidroterapia, toros, conciertos, baile- se incluye una viñeta referida al deporte de la esgrima.

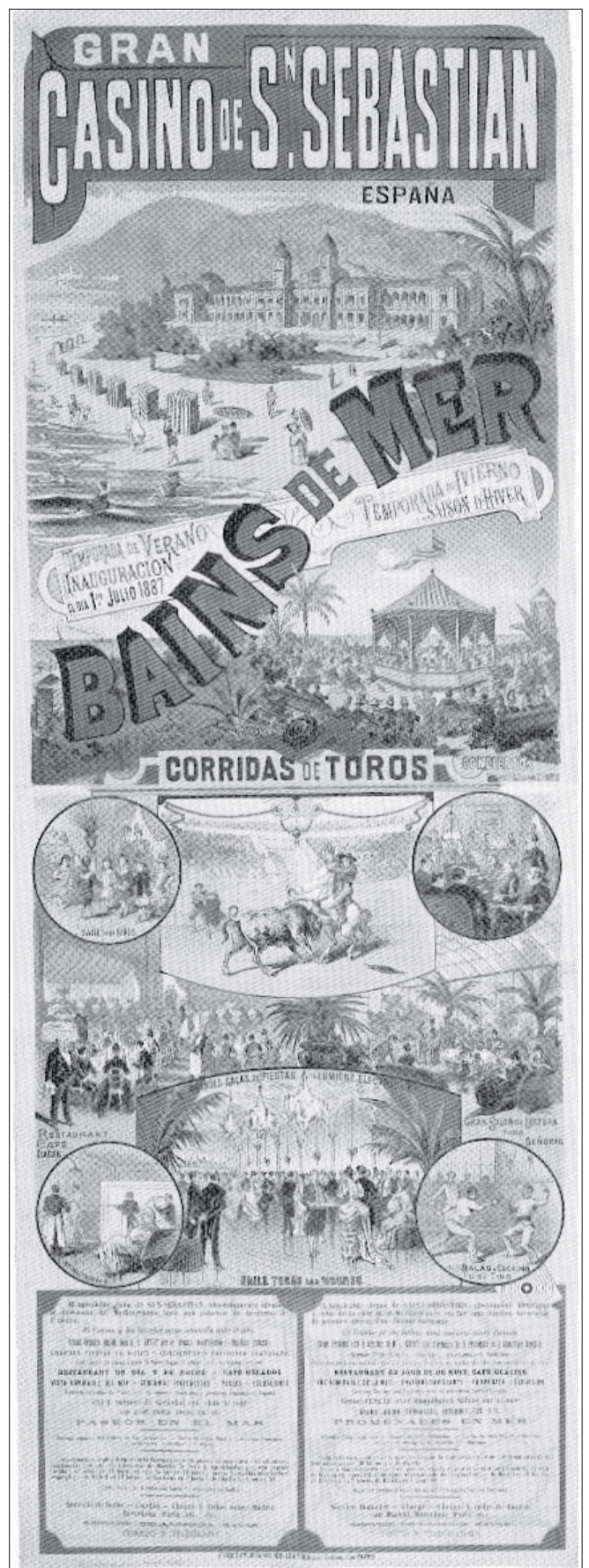

Fig. 2. Casino de San Sebastián. Anónimo. 1887

Recordemos que la reina Isabel II había puesto de moda, tiempo atrás, esta ciudad al elegirla como lugar de descanso y recreo, y para la práctica salutífera de los baños de mar. Fue, en efecto, en 1845 cuando, aconsejada por su médico para curarse una infección de la piel, la reina apareció por la Bella Easo y tras ella acudieron los miembros del gobierno, la corte y la aristocracia en pleno, además de visitas reales desde otros países europeos lo que le dio a la ciudad ese noble porte del que ha hecho gala. En la época del cartel, coincidiendo con la inauguración del Gran Casino, San Sebastián llevaba pues más de cuarenta años como centro de vacaciones y estaba considerado una estación balnearia a la altura de Montecarlo, Wiesbaden, Spa, Vichy u Ostende.

El cartel demuestra que las costumbres higiénicas y deportivas no eran extrañas al público habitual del Casino, es decir: ilustres personajes de la política, la cultura y la economía, aunque indudablemente los baños de mar, junto al propio Casino, son los protagonistas del mensaje.

Puesto que nuestro interés se centra, en este caso, en el deporte no me entretendré en otros aspectos sin duda relevantes del mensaje. La esgrima en el siglo XIX estaba lejos de ser el entrenamiento militar que había sido en otros tiempos; aunque un dato que nos indica su valor, todavía en aquellos momentos, es que algunos periódicos (según cuenta Cansinos- 
Asséns en sus memorias, La novela de un literato, vol. 1) incluían en sus sedes salas de esgrima donde los "plumillas" se ejercitaban en el arte del sable y el florete, dispuestos a defender con el acero lo que habían defendido previamente con la pluma y la tinta. La espada conservaba todavía un valor simbólico, con ella se defendía el honor

En cualquier caso, la esgrima era un deporte de caballeros, perfectamente masculino por entonces (Fig. 3). En el cartel quedan bien definidos los apartados masculinos y femeninos de la vida social, ellas tenían el "salón de lectura para señoras", ellos el "club" (lugar donde se jugaba a las cartas y se fumaba, pues entonces no se fumaba delante de las señoras) y las "salas de esgrima y de tiro". El tiro (así como la caza) era también un noble deporte apropiado para las clases pudientes. Aparece representado por una diana ubicada bajo la ventana dedicada a la esgrima. Luego estaban los ambientes mixtos: conciertos, "Restaurant y café glacier" y el baño, aunque en la playa aparecían hombres y mujeres divididos por una cuerda vigilada convenientemente.

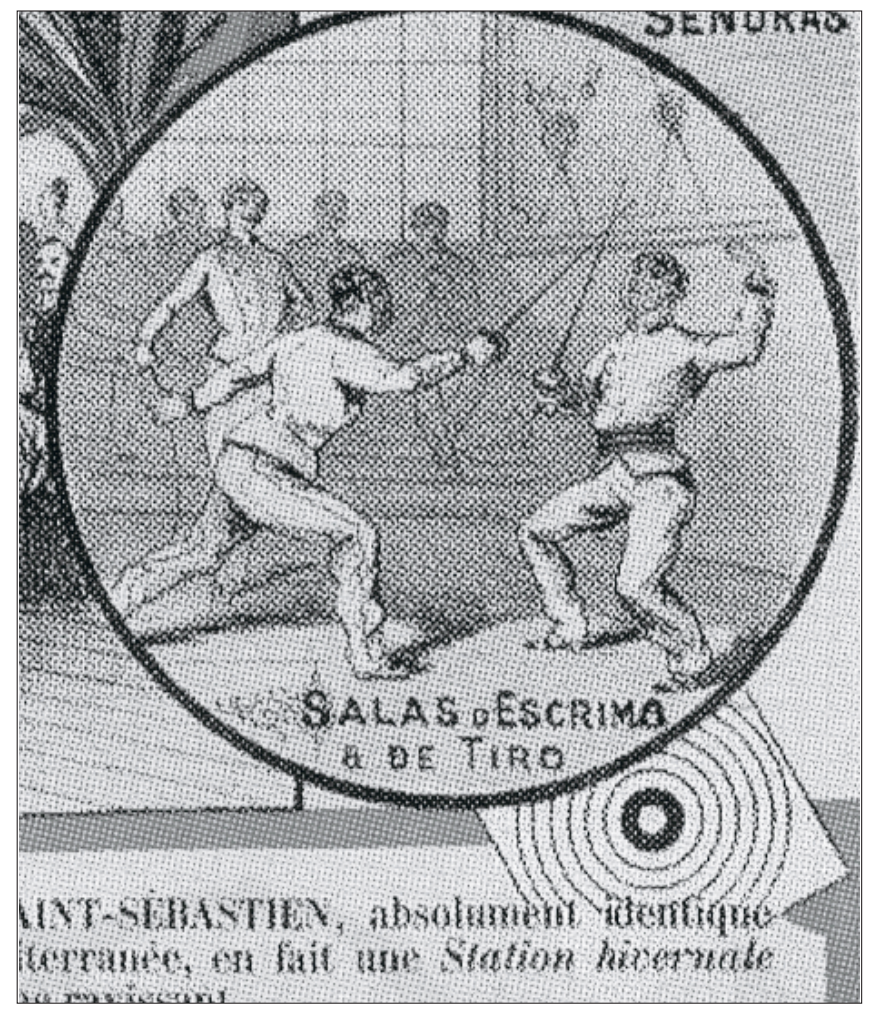

Fig. 3. Casino de San Sebastián. Detalle. 1887

Entrando ya en el siglo XX, nos encontramos con otras clases de deportes más burgueses: ciclismo, tenis, alpinismo, natación, esquí, remo, automovilismo, etc. Casi todos los casos se refieren a deportes que se practican individualmente $o$ en parejas, son más raros los deportes de equipo. Las figuras representan a una clase social elevada, alta burguesía, que era la que fundamentalmente disponía de tiempo y dinero para practicar el deporte. Los deportes de equipo, aquellos cuya práctica no necesitaba de mucho equipamiento, quizá un simple balón, resultan mucho menos representados, no porque no fuesen practicados sino porque resultaban más próximos a las clases bajas. Lo que indica que tanto el deporte como la publicidad constituían, por entonces, actividades clasistas. El cartel del Concurso Nacional de Juegos Atléticos (1909, nueve años antes de la fundación de la Federación Española de Atletismo), además de por su antigüedad es interesante por su riqueza iconográfica ya que en él se combinan referencias clásicas (las coronas de laurel, el discóbolo) junto a la representación de deportes más modernos y burgueses (la carrera con obstáculos y el tenis). 


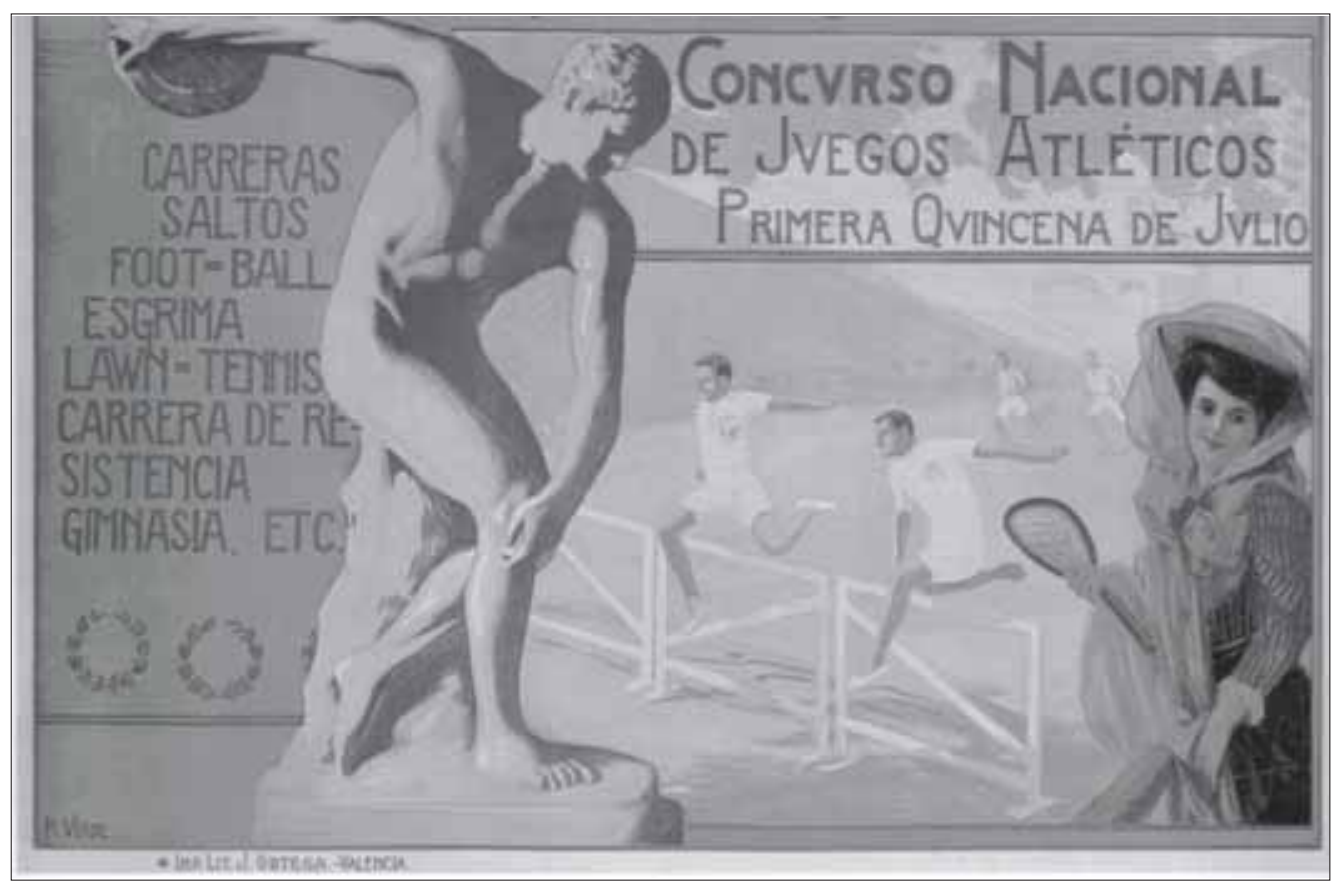

Fig. 4. Concurso Nacional de Juegos Atléticos. R. Verde, 1909

Es obvio, por el texto que forma parte del cartel, que la representación del discóbolo tiene un exclusivo valor simbólico: nada se menciona en él del lanzamiento de disco, mientras que se especifica la presencia de "carreras, saltos, foot-ball, esgrima, lawn-tennis, carrera de resistencia, gimnasia". De hecho la figura del discóbolo constituye uno de los iconos más fácilmente reconocibles en el entorno vinculado al atletismo y el deporte, más "tópicos" en el sentido de la extensión de su uso, a pesar de no ser el disco una de las modalidades de atletismo más seguidas en nuestros tiempos. Es también notable la opuesta actitud con que son representados los hombres (en acción, corriendo y saltando) y la mujer, armada con su raqueta pero posando para el retratista. Esta actitud indolente que es todavía más clara en otros mensajes (Fig. 6) corresponde al arquetipo iconográfico de la época, la mujer lánguida, apática, pero también a un cierto imaginario de la época: la mujer de clase alta era de salud débil, quebradiza, de fácil desvanecimiento (seguramente provocado por el ayuno voluntario y las apreturas del corsé); frente a la mujer trabajadora, fuerte, voluntariosa, robusta, puesto que de otra forma -añadiríamos ahora- no hubiese sido posible su supervivencia en un entorno tan poco complaciente.

No todos los mensajes sobre deporte corresponden a competiciones, carreras, exhibiciones u organizaciones deportivas. En cuanto a los anuncios vinculados a la bicicleta, sólo una parte incumbe directamente al deporte, siendo otros propios de los fabricantes de las máquinas, aunque no falten en ellos las referencias deportivas: lo que aparece en el mensaje no es el objeto aislado y estático sino situado en acción a veces por mujeres (Fig.5).

El empleo de la figura femenina había sido puesto en boga por los anuncios del francés Jules Chérèt y su silueta, muchas veces con un sentido ornamental propio de las ideas estéticas del momento, poblaba los mensajes comerciales. Pero en otras 
ocasiones (reconstituyentes, vigorizantes capilares, moda, cosmética, corsés) se trataba de mercancías expresamente dirigidas a un creciente mercado femenino. Los grandes almacenes de París, ciudad de la que irradiaban muchas de las costumbres modernas, ofrecían cursos gratuitos a las señoras para aprender a montar en bicicleta; así que entendemos que estos anuncios no ofrecían una representación meramente decorativa de la mujer, sino que en efecto iban expresamente dirigidos a ellas como potenciales compradores.

Los anuncios de ciclismo, carreras y competiciones, son, sin embargo, ocupados por esforzadas figuras masculinas, las señoras aparecen aquí como meros testigos, acompañantes y admiradoras de los animosos atletas. La mujer ciclista aparecía, por el contrario, en otro tipo de contexto, escenas al aire libre, paseos por el campo, etc. Fijémonos, de una forma un poco más detallada en este mensaje.

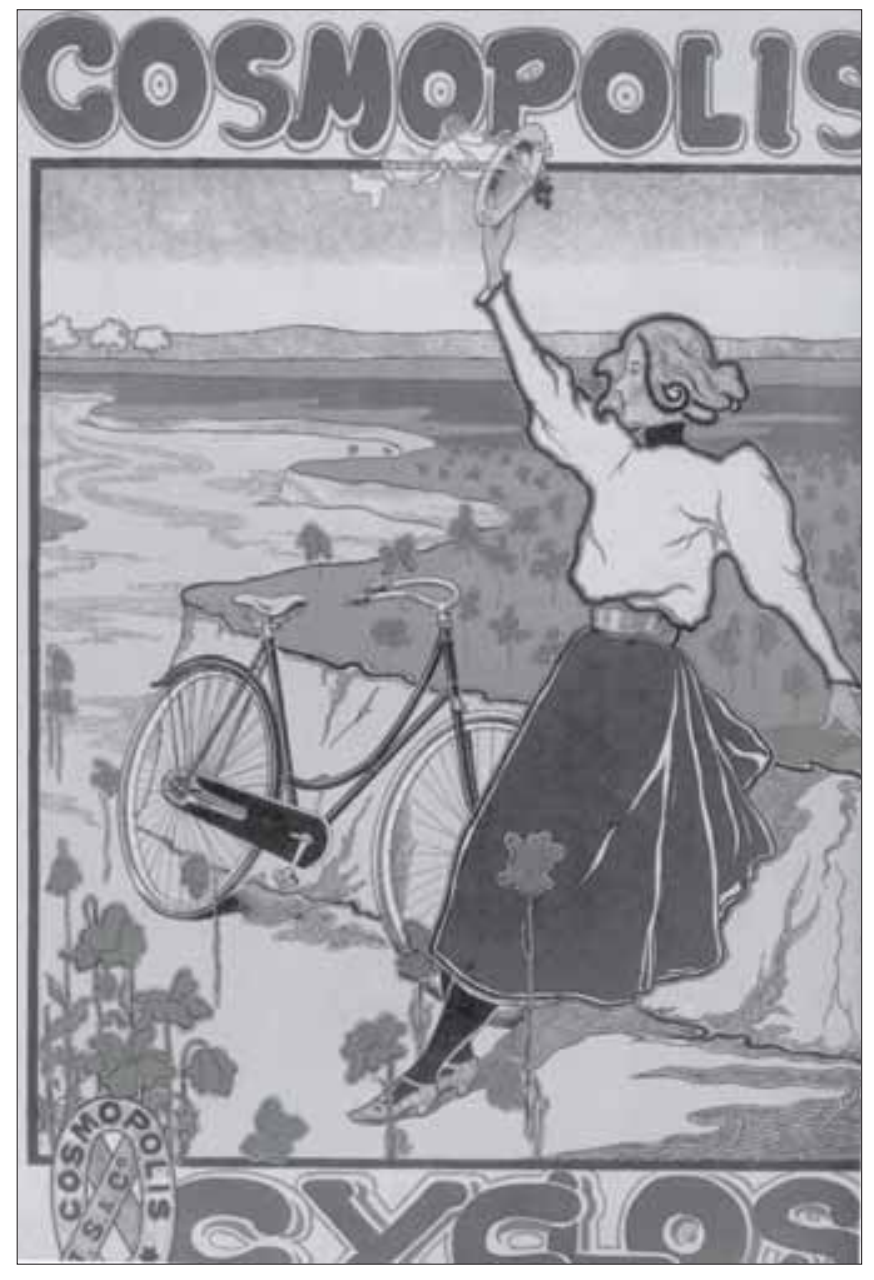

nos recuerda la dualidad naturaleza-industria.

Fig. 5 Ciclos Cosmópolis. A. Gual, 1901

El cartel manifiesta las características típicamente modernistas: el trazo sinuoso, los arabescos, el movimiento, el grueso perfilado fruto de una inspiración japonesista o tomada de las vidrieras góticas, que influyeron también a otros autores de la época. En conjunto las influencias, en este caso, son más orientalizantes que neomediavalistas.

Dado el momento en que se produce el mensaje, estamos legitimados a pensar que todo tiene una intención: la figura femenina, el perfil serpenteante del paisaje, las flores rojas.

La figura delicada de la mujer hace referencia a la supuesta fragilidad femenina. El estrecho talle acentuado por el ancho cinturón, que refuerzan la imagen quebradiza, al igual que los tobillos finos.

La presencia dominante del paisaje

Las flores, tan del gusto de los artistas del modernismo, representan la belleza y lo efímero; y el color rojo simboliza la pasión. Más en concreto en la tradición cristiana, la amapola representa el sueño, el abandono, la indiferencia.

La máquina no tenía en verdad mayor protagonismo en unos que en otros, porque 
en general, en los años de la Belle Époque, las máquinas (bicicletas, primeros automóviles, estufas, etc.) eran todavía consideradas antiestéticas (la industria -había dicho Oscar Wilde- es la raíz de toda fealdad) y los mensajes de los futuristas italianos, exaltando la imagen del automóvil, todavía no habían calado entre la población, ni entre los anunciantes.

Los anuncios de actividades deportivas han ido evolucionado más desde un punto de vista de estilo y de técnicas que iconográfico, no sólo porque el repertorio de los deportes no ha variado demasiado desde los años a los que pertenecen los primeros anuncios, sino porque se ha seguido recurriendo a una cierta épica del deporte, una mitificación de los deportistas, casi más estatuas que personas (incluso, o todavía más, cuando se empezó a utilizar la fotografía), una reserva de signos vinculados con el triunfo: el podio, el laurel, el gesto de victoria, la meta alcanzada, el obstáculo superado; mucho más que con el sudor, el dolor, el esfuerzo y el sacrificio. En este sentido son operaciones retóricas propiamente publicitarias: atenuación de los elementos penosos o esforzados y exaltación de los gozosos y alegres. El deportista no sólo aparece como triunfador, también es apuesto o gallardo, como aquellos carteles de reclutamiento del siglo XVII o XVIII donde siempre aparecía representada la figura garbosa del militar como principal atractivo.

Quizá el elemento más interesante en este sentido es el de la representación femenina. El cambio fundamental se produce en los años treinta. Hay que recordar que como consecuencia de la Primera Guerra Mundial el papel social y laboral de la mujer se modificó de forma radical e irreversible. Su cambio de posición en el espacio social supuso también una transformación de la moda (ropas más cómodas), en el consumo (más interés por mercancías con un valor simbólico) y un cambio en el imaginario social (una mujer activa frente a la imagen indolente del pasado).

Ya en la publicidad de los años veinte hay algunos ejemplos de ello, pero sobre todo es en la década siguiente donde esa nueva mujer, dinámica, deportista, trabajadora, irrumpe con más fuerza. La mujer aparece fumando, bailando los nuevos ritmos, escuchando discos en el gramófono, etc. pero ya no es la "demi mondaine" de Chérèt, de dudosa moralidad, sino una nueva burguesa (por supuesto, esa figura no refleja a la mujer obrera), moderna y, hasta cierto punto, liberada.

Sin movernos del deporte del tenis, veamos un anuncio de 1938 (Fig. 6), no solamente aparece ella como una activa deportista, no está reclinada ni apoyada sino jugando, su propia fisonomía ha cambiado. Su cuerpo no es frágil, ni su actitud es lánguida. El cuerpo es fuerte, el gesto vigoroso. No es, en definitiva, un mero adorno. 


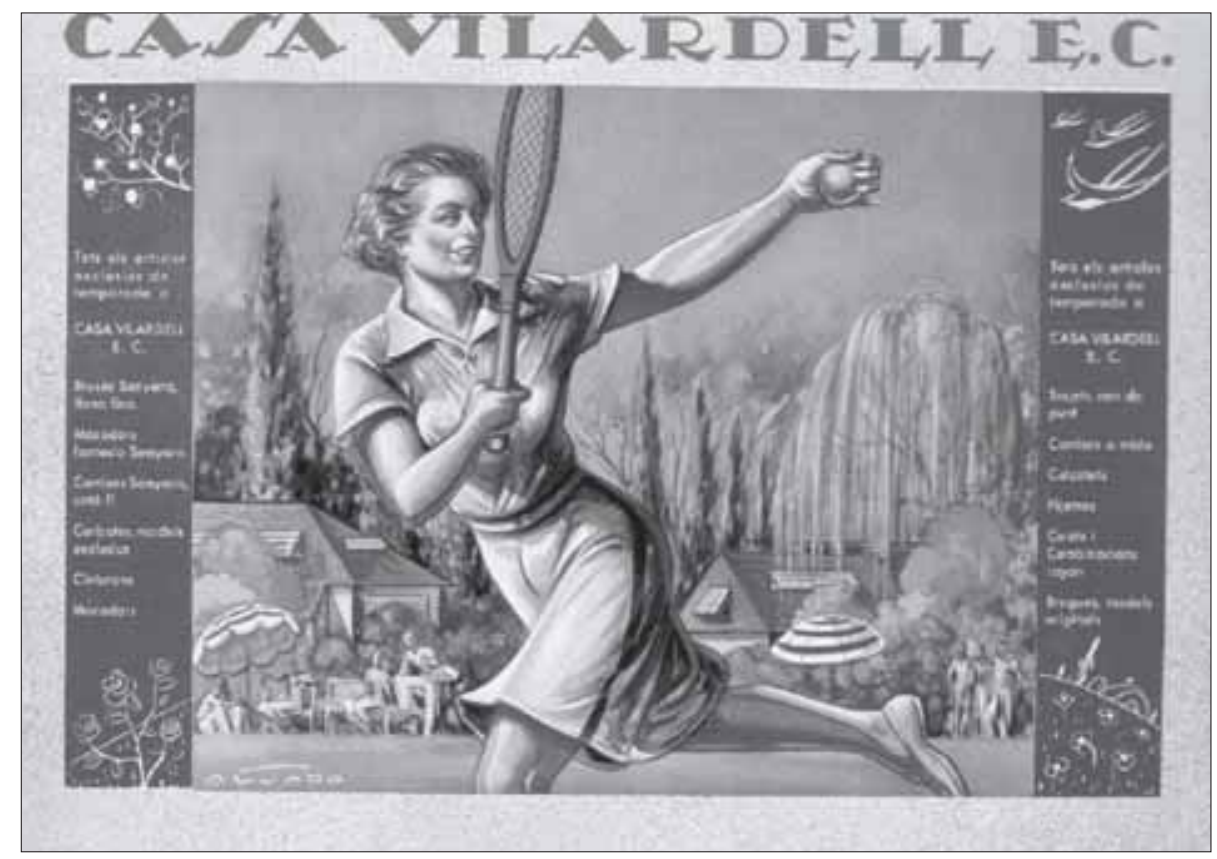

Fig. 6 Casa Vilardell E. C. V. Aguado, 1938

\section{EI deporte en la publicidad}

¿En qué momento el deporte y los deportistas se constituyen en un valor (y por lo tanto en una guía) de nuestra sociedad? En el momento, podríamos asegurar, en que son empleados por la publicidad como palanca de impulso para vender mercancías. Ya no son anuncios de deporte (concursos, carreras, etc.), no se trata de "vender" el deporte (o una asociación deportiva), se trata de vender otra cosa, cualquier cosa, empleando para ello el atractivo del deporte.

Hay en esto dos etapas, una de ellas bastante remota en la que aparece el deporte, en abstracto, vinculado a algunas mercancías. Por ejemplo, el conocido display de Segrelles para el papel de fumar Gol (1920). Todavía hay un ejemplo más antiguo de la misma marca, una chapa esmaltada de 1910 donde se aprecia a un futbolista en plena acción (Fig. 7). Algo parecido ocurre con los anuncios de calzoncillos Olimpic (c. 1950) en los que además de los anillos olímpicos, la figura del protagonista, que no muestra su cabeza, es la de un deportista que sujeta un balón. No son, si embargo, ejemplos demasiado puros puesto que en estos casos la referencia parecía obligada por el nombre del producto: "Gol-fútbol", "Olimpic-olimpiadas". 


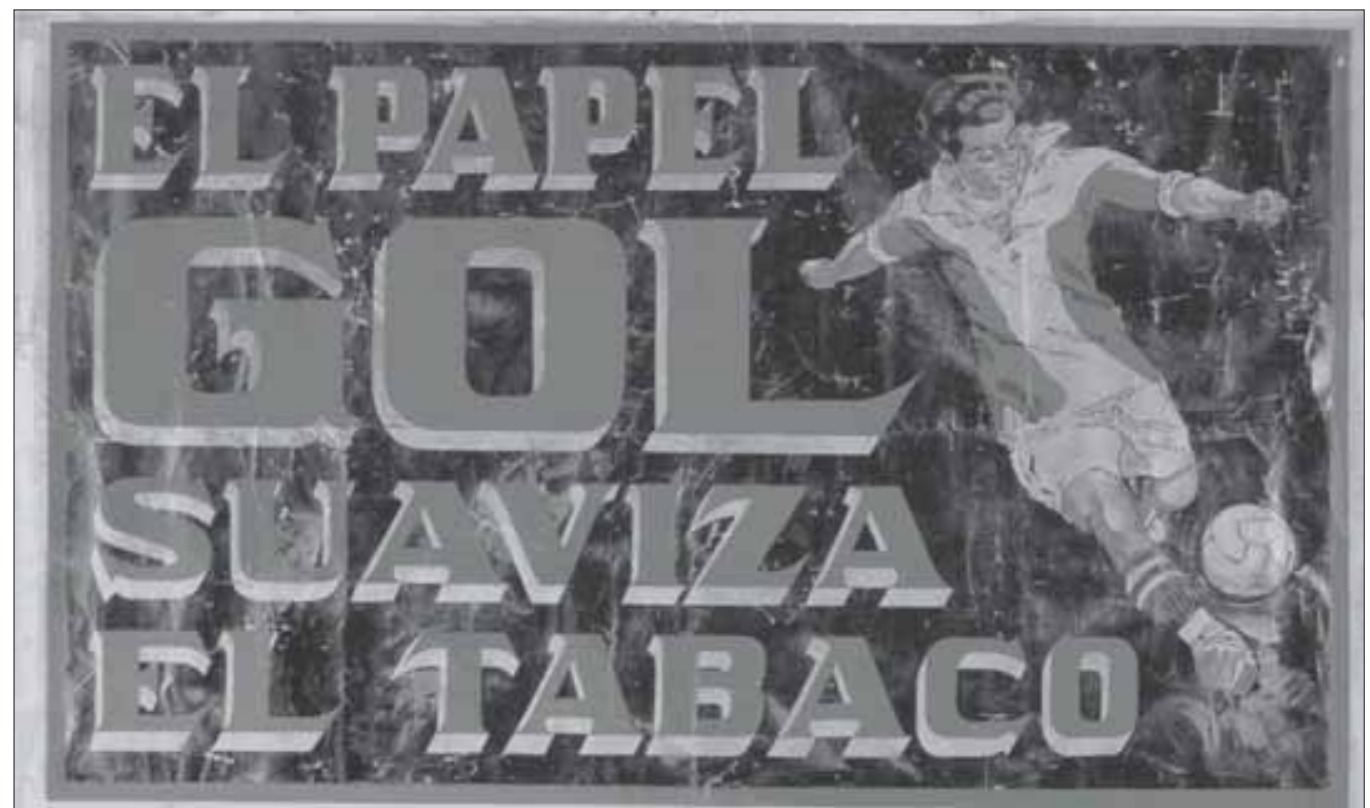

Fig. 7. Papel Gol. Segrelles. 1910

En otros casos no es el nombre de la marca sino el tipo de producto el que establece vínculos directos con actividades deportivas: bañadores-natación, ropa de abrigo-esquí, zapatillas-tenis, etc.

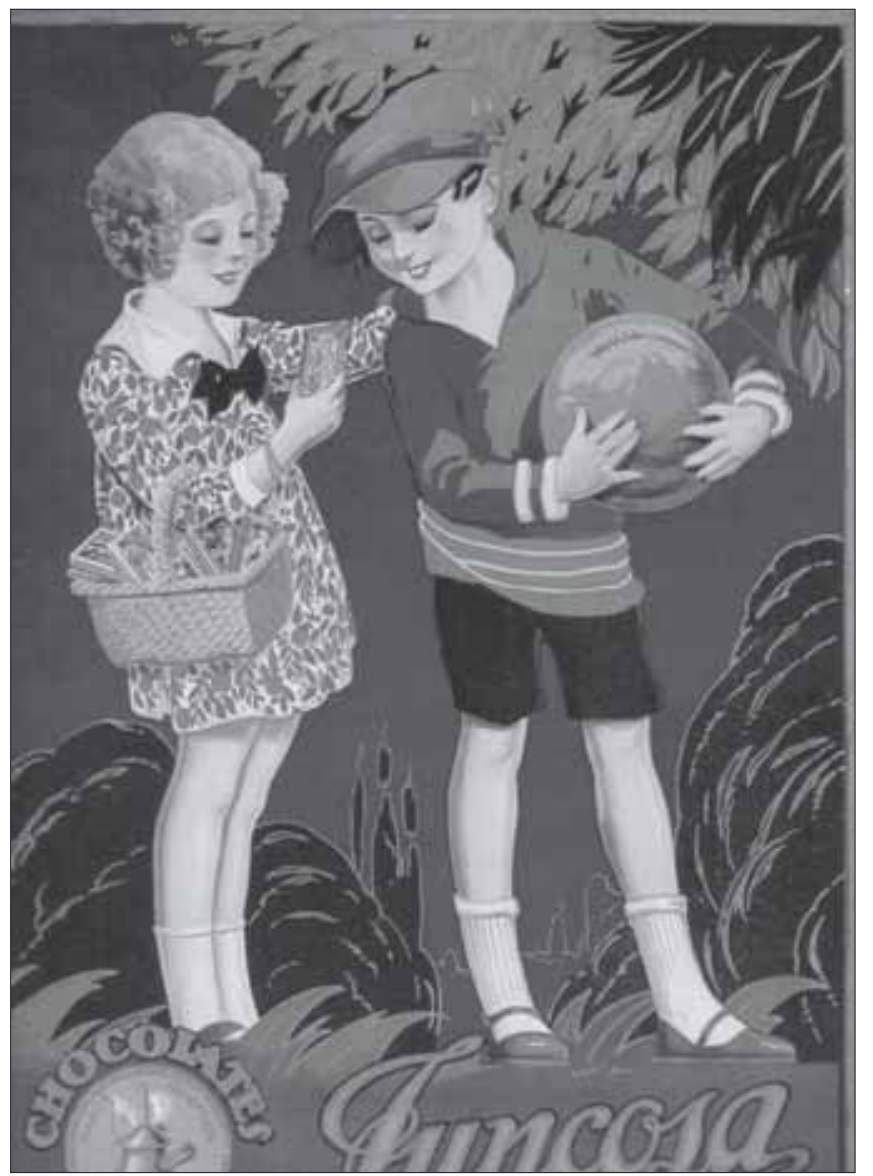

Fig. 8. Chocolates Juncosa. Anónimo. 1930

Un pequeño cartel de escaparate de 1930 resulta en este sentido más representativo de lo que buscamos (Fig. 8). El producto es una marca de chocolate, aunque en realidad más que el dulce lo que se está anunciando son los cromos, aquellos cromos que regalaban con los chocolates y que los niños de la época coleccionaban ávidamente. El muchacho representado es un jugador de fútbol, un portero, pues lleva la gorra que entonces los distinguía. Pero la figura que aparece representada no es en realidad la de un deportista sino la de un niño, los aditamentos deportivos (la gorra y el balón) en este caso no significan "deporte" sino "infancia". 
Mucho más tardío y más significativo es cuando aparece el deporte con nombre propio. Ya no son arquetipos sino retratos de deportistas perfectamente identificables que funcionan como portavoces. Es el momento en el que el deporte adquiere toda su dimensión de espectáculo y ocupa no sólo los espacios publicitarios sino una buena parte del contenido de los medios de comunicación: películas de tema deportivo, retransmisiones radiofónicas de partidos, publicaciones especializadas. Y ello, tanto en España como en el resto de Europa, se produce sobre todo alrededor del fútbol que alcanza una inédita dimensión social y -en un contexto todavía más global- con las olimpiadas. Ya no es puramente un deporte, es una forma de expresión e identificación para el espectador, no sólo psicológica, también ideológica. Los conflictos entre los países ahora se reproducen en el campo deportivo, el deporte sirve como válvula de escape a los fervores nacionalistas y es empleado como elemento propagandístico de primer orden. De hecho las olimpiadas han sido siempre una herramienta manejada con el fin de mostrar la superioridad de un país (Inglaterra), de una raza (Alemania) o de un régimen político (USA, URSS).

La conversión del deportista en portavoz publicitario se produce en España con dos figuras futbolísticas; Kubala (chicles Dunkin) y, sobre todo, Alfredo Di Stéfano (medias Berkshire). Previamente habían sido tratados por el cine ( ¡Kubala!! Los ases buscan la paz, 1954; Saeta Rubia, 1956; La batalla del domingo, 1963).

El anuncio de medias Berkshire resultó tan impactante, para la época, y para el símbolo que era entonces el Real Madrid, que Di Stéfano se vio obligado a devolver el cheque recibido por su presencia en el anuncio (175.000 pesetas) y a pedir que retirasen el mensaje (Fig. 9). La empresa anunciante lo hizo con mucho gusto; había conseguido un impacto arrollador y además no le había costado un duro. El escándalo, pues lo hubo, demostró hasta qué punto el deporte se había transformado en algo sagrado, en otro sustituto de la religión. Era un pecado que un semidiós, un héroe del deporte como Di Stéfano, se prestase a esas indecentes maniobras comerciales.

El anuncio de prensa de la agencia Arce \& Potti (hubo también versión de radio), mostraba un cuerpo partido por un letrero en el que la mitad superior correspondía al famoso futbolista y la inferior a un par de bonitas piernas de mujer, acompañadas de un balón de fútbol. El texto: "Si yo fuera mi mujer... luciría medias Berkshire".

Hoy nos puede asombrar esa polémica, pues nuestra publicidad está llena, no ya de deporte, sino de deportistas: Fernando Alonso, Gasol, Nadal, Indurain, Beckam, Ronaldo, etc. venden relojes, lubricantes de automóvil, ropa interior, desayunos, gafas de sol, bancos, etc. Y el hecho de su uso publicitario masivo certifica su prestigio en nuestro escenario social.

Pero la asociación que elaboraba el anuncio entre el famoso jugador y una mercancía era, en ese momento, "la ruptura, la sorpresa, la locura: todo un antecedente" según fue descrito en el artículo "Campañas que hicieron historia" (Bravo, J. et al.: 1994: 22). Todos los demás llegaron después, ya en plena época de la televisión: Kubala y chicles Dunkin, Cruyff y pinturas Bruguer, Pedro Carrasco y Motor Ibérica, Ángel Nieto y Motofeber. Técnicamente no era más que un simple y tosco fotomontaje pero el resultado resultaba tan agresivo como lo fueron años más tarde 


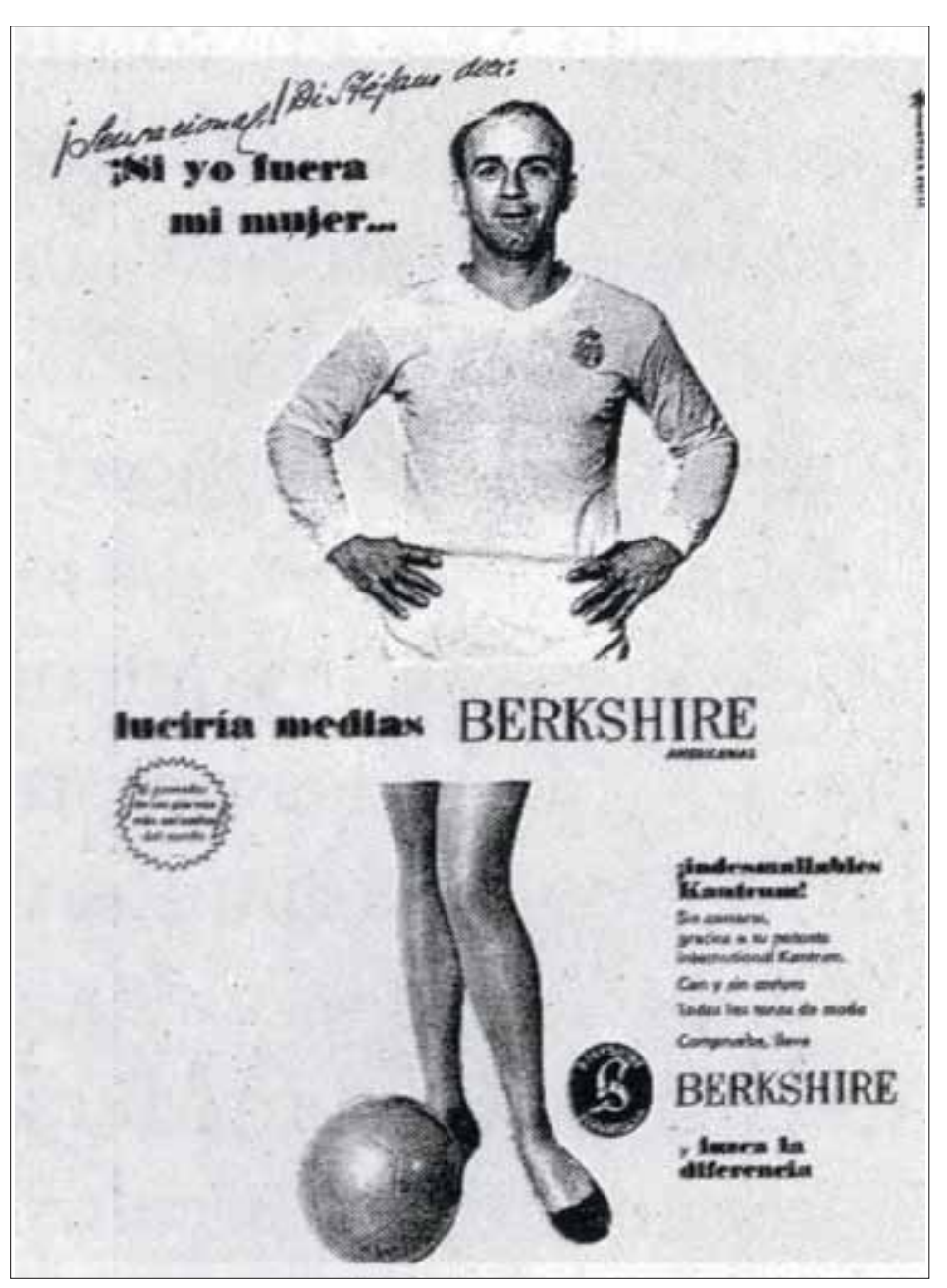

Fig. 9. Medias Berkshire. Agencia Arce \& Potti. 1962 los anuncios de Toscani, asociando impactantes imágenes documentales con una marca comercial (Benetton). A diferencia de épocas anteriores la publicidad apoyaba todo su peso no en la fuerza estética del mensaje (como en el anuncio de Ciclos Cosmópolis de la Fig. 5) sino en el peso social de lo representado $y$ en el contraste de significados asociados a los dos elementos del montaje: hombre-mujer, fuerza-delicadeza, rudezasuavidad, etc.

Es obvio que el resultado no hubiese sido el mismo si en la imagen hubiese aparecido un futbolista desconocido o un actor haciendo las veces de deportista. El valor del signo residía en lo que en aquellos momentos representaba ese deportista concreto en un contexto histórico concreto.

Repasando la historia del testimonial, nos encontramos con una notable evolución de los personajes representados. En una primera etapa dominaron los personajes de la realeza, históricos e incluso mitológicos realizando "falsos testimonios": la Reina Victoria o el Papa anunciando cubitos de sopa, en un escenario fuera de todo control legal y deontológico. Luego llegaron actrices de teatro (Sara Bernhardt) y cantantes de ópera (Caruso); después fue el dominio de las estrellas del cine (toda la campaña de Lux "Nueve de cada diez estrellas usan Lux"), cantantes ligeros y modelos de alta costura. Es la hora de los deportistas, porque el descrédito de la mayor parte de los sectores sociales y profesionales (políticos, financieros, periodistas, intelectuales, ...) es de tal calibre que casi no queda otro remedio que acudir a los deportistas como portavoces. Es verdad que siguen apareciendo cantantes (Luz Casal), cocineros (Arzak, Adriá), actores de series de televisión, presentadores, pero nada comparable a la invasión del deporte en horas de programación y en testimonios publicitarios.

El deporte ha demostrado además su versatilidad para vincularse a casi cualquier clase de mercancía, dependiendo del valor que se quiera destacar: resistencia, forta- 
leza, vigor, triunfo, salud, belleza, libertad, energía, solidaridad, superación, entrega, sacrificio, constancia, etc.

Una misma actividad puede significar cosas bien diferentes según la situación en la que aparece representada. Tomemos dos ejemplos de boxeo. El primero de ellos es un anuncio de 2006 (Fig. 10), el segundo un anuncio de los años sesenta (Fig. 11).

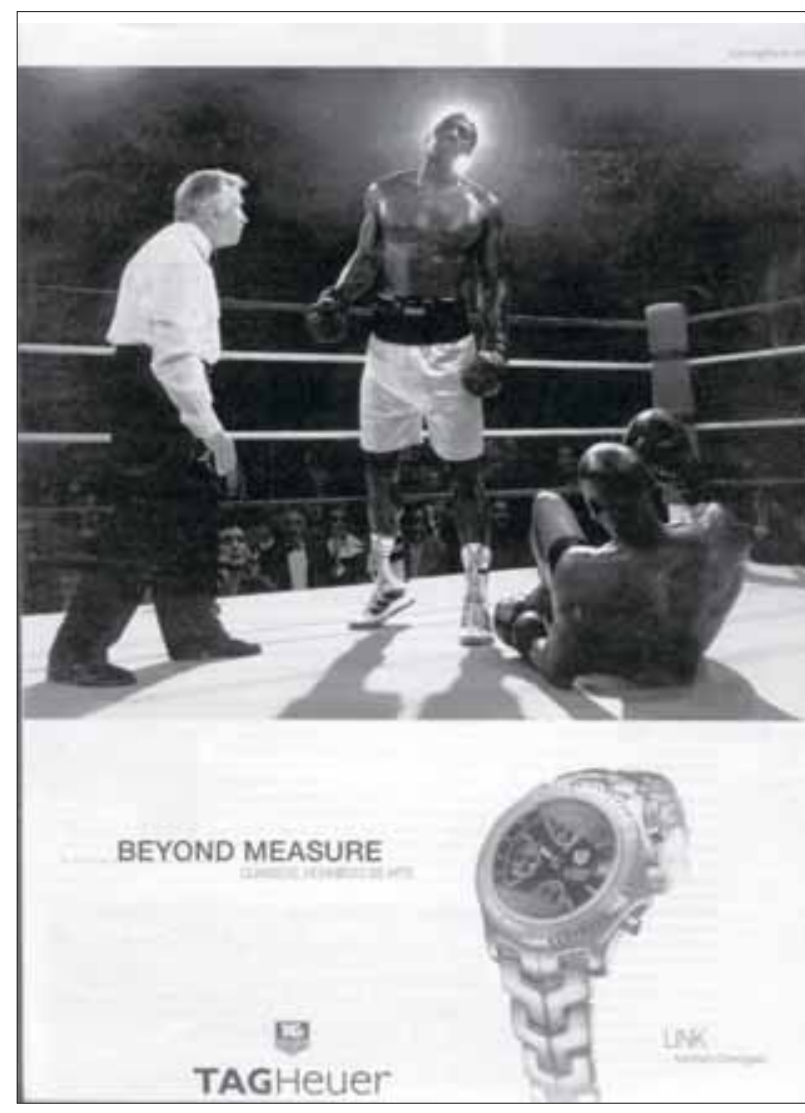

Fig. 10. Publicidad gráfica de relojes Tagheuer. 2006.

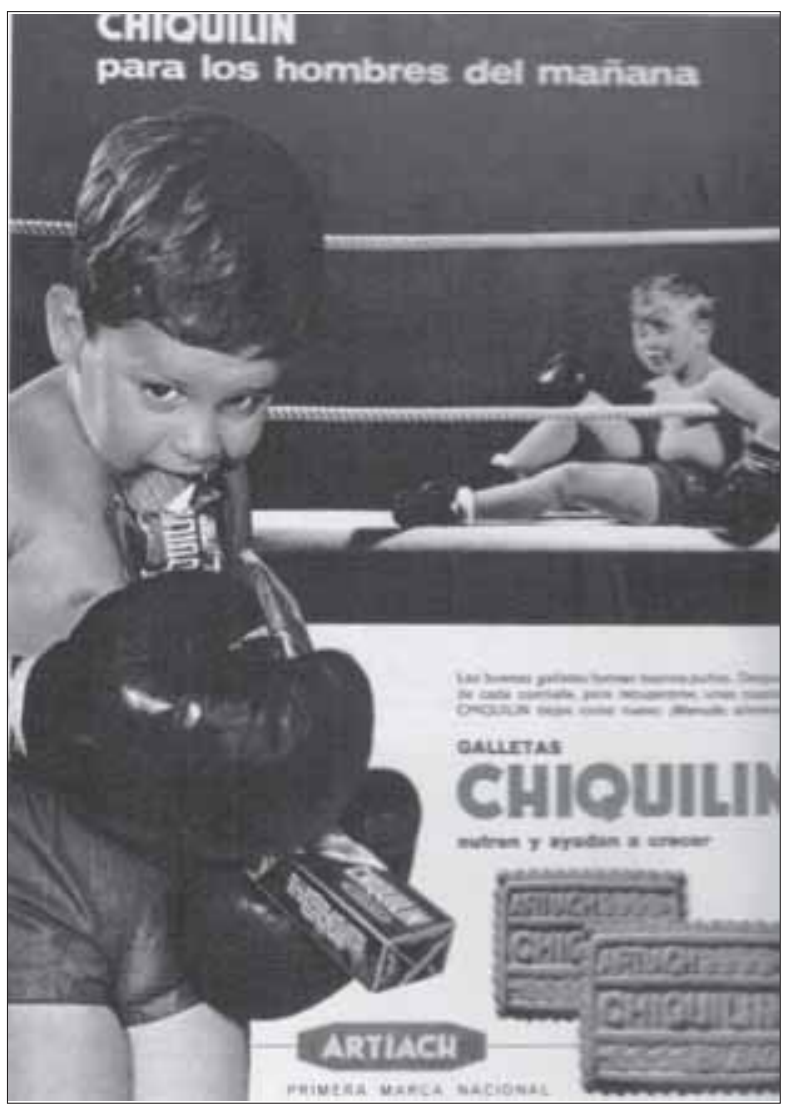

Fig. 11. Chiquilín. Agencia OESTE. 1965

El procedimiento retórico habitual en este tipo de mensajes gráficos es el de un "deslizamiento metonímico" por el que el producto (relojes, galletas) se contagia con los significados del otro elemento que le acompaña (boxeo). Lo que en el anuncio actual se resuelve simplemente por la proximidad de los dos elementos en el interior del mensaje, en el más antiguo se vuelve literalidad: el pequeño boxeador aparece comiendo las galletas, mientras que su rival (que no las come) aparece derrotado en el cuadrilátero. El creativo no ha querido dejar demasiado abierto el mensaje, como si desconfiase de la capacidad decodificadora del receptor: es el alimento del triunfo. Una retórica sin sobresaltos, como corresponde a una época de mayor inocencia del espectador.

Ahora bien, cada uno de los mensajes actualiza un valor diferente partiendo del abanico de significados que puede incorporar un deporte: solidez, resistencia a los golpes, potencia, precisión, en un caso; energía, triunfo en el segundo. 
No hay deporte de alguna importancia donde no exista actualmente una presencia de la tecnología, más allá de aquellos que utilizan máquinas como parte integrante de la modalidad deportiva: ciclismo, automovilismo, motorismo. Incluso en aquellos que utilizan las máquinas más básicas, como la palanca, necesitan hoy del concurso tecnológico; pértigas, raquetas, remos,... El calzado, los equipamientos, cascos, uniformes, se convierten en prodigios tecnológicos, utilizan materiales como la fibra de vidrio, el titanio, el aluminio o el neopreno; los deportistas siguen una alimentación "científica". Por ello también los fabricantes de máquinas (relojes, automóviles) se encuentran entre los anunciantes más característicos que vinculan sus invenciones al deporte: fortaleza, exactitud, resistencia, son los valores que manejan.

El anuncio de la Fig. 12 nos muestra a un deportista bien conocido en la actualidad, Fernando Alonso, anunciando ¡una encimera para cocina! El registro verbal del mensaje puede ayudarnos a desentrañar este misterio: "Fernando Alonso sólo confía en la mejor tecnología para dirigir su vida profesional y personal. Por eso elige Silestone". El secreto es... la tecnología.

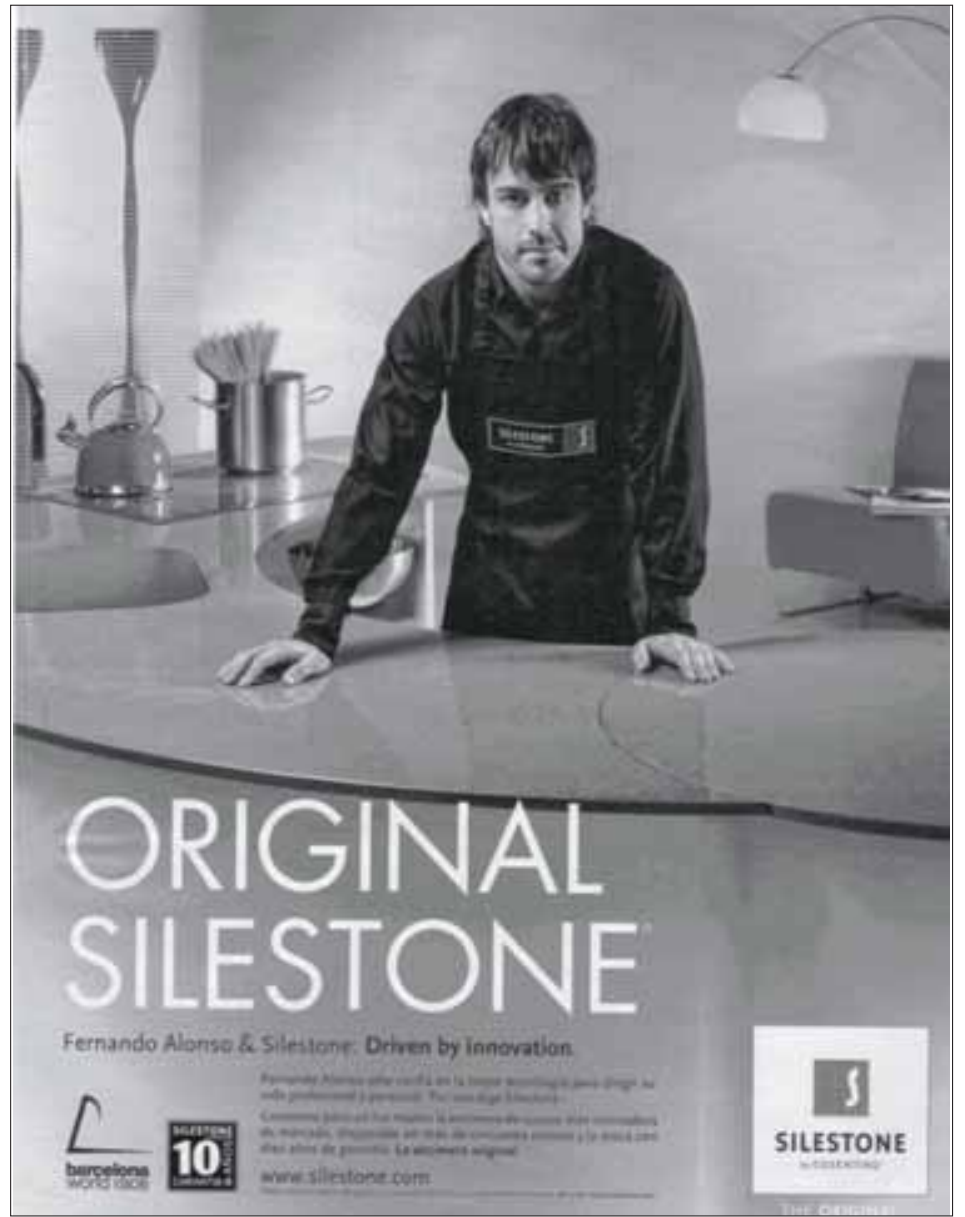
entre los dioses. No es sólo arte,
como dice el eslogan "Cada sábado transformamos en baloncesto en arte", es religión.
Fig. 12. Silestone, c. 2005

Casi cualquier disculpa es buena para construir un mensaje alrededor del deporte. Un desodorante: "A los jugadores cuanto más sudan más se les quiere. A ti no". Una cerveza: "Este año 25 jugadores ganaron la Liga, pero fueron millones los que levantaron la Copa". Un reloj: "inspirado por los automóviles GT más contemporáneos y tecnológicamente avanzados". Un canal de televisión: "Llegar al número uno no ha sido fácil". Un whisky que da la vuelta al argumento "si bebes no conduzcas": "La mejor fórmula / El que conduce no bebe". En el anuncio de la Figura 13, el deporte se eleva a los altares, los deportistas son colocados entre los dioses. No es sólo arte,
en baloncesto en arte", es reli( 

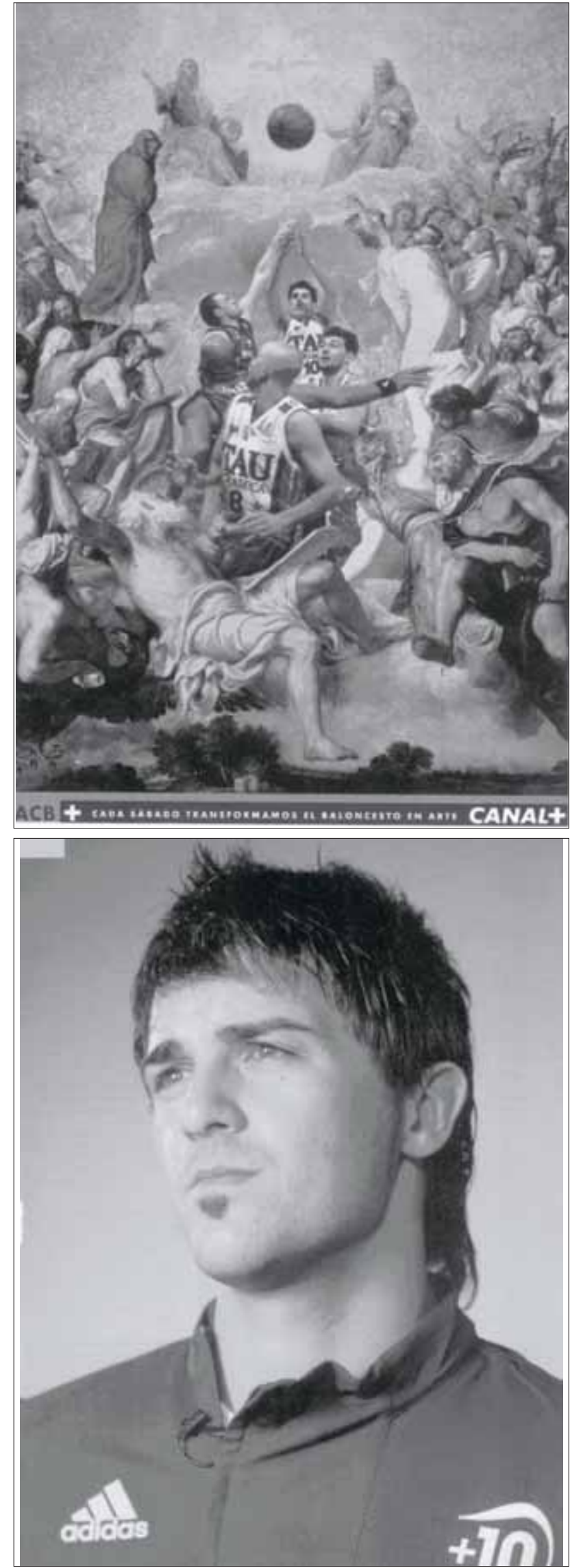

Fig. 13. Canal +. Agencia Contrapunto. 1999

Es inevitable que haya sido cada vez más el testimonial, el formato publicitario elegido para la publicidad de argumento deportivo. Gracias a la televisión, el deporte ha adoptado un sistema de star-system muy parecido al del cine de su época de oro.

\section{El deporte como publicidad.}

El deporte no podría vivir hoy sin la existencia de los patrocinadores; pero también es cierto que la publicidad lo tendría mucho más difícil sin la existencia del deporte. El deporte le garantiza la audiencia, la constitución de un público entregado, la repercusión mediática sin las estrecheces de los bloques publicitarios.

En un primer momento, entre deporte y publicidad existe un intercambio. La una proporciona el dinero sin el cual sería imposible el deporte global de nuestro tiempo; el otro le ofrece soportes, pero también argumentos.

Los mensajes se deslizan de los cartelones de los estadios, de las banderolas, las metas volantes, a los cuerpos de los atletas que se revisten con los logotipos y símbolos de sus patrocinadores. Los deportistas se convierten en hombres-anuncio, como aquellos hombres sandwich del siglo XIX; pero los actuales no arrastran un cartelón, ellos son el cartel. El anuncio no tapa al hombre, el anuncio es el hombre.

Fig. 14. FútbolLife. 2007 
Una entrevista con el futbolista David Villa (Figura 14). Villa exhibe en la fotografía que acompaña la entrevista, meramente documental en apariencia, la marca de su firma patrocinadora. La publicidad escapa del rígido armazón de sus espacios tradicionales para reaparecer convertida en periodismo (como en este caso) o en cine o en música. Es la publicidad invisible, la publicidad que no dice su nombre.

Un reportaje periodístico sobre nuestros atletas olímpicos deviene soporte publicitario (Figura 15, ver la colección de marcas en la cartela inferior). En él aparecen como héroes de la clase trabajadora, como obreros del adiestramiento, subrayando el carácter sufridor del atletismo. Una representación que parece inspirada en el realismo social soviético se combina con las marcas comerciales, símbolo capitalista por excelencia, porque la publicidad es capaz de conciliar -dentro de su discurso habitualmente euforizante o exaltativo- las opciones más extremas.

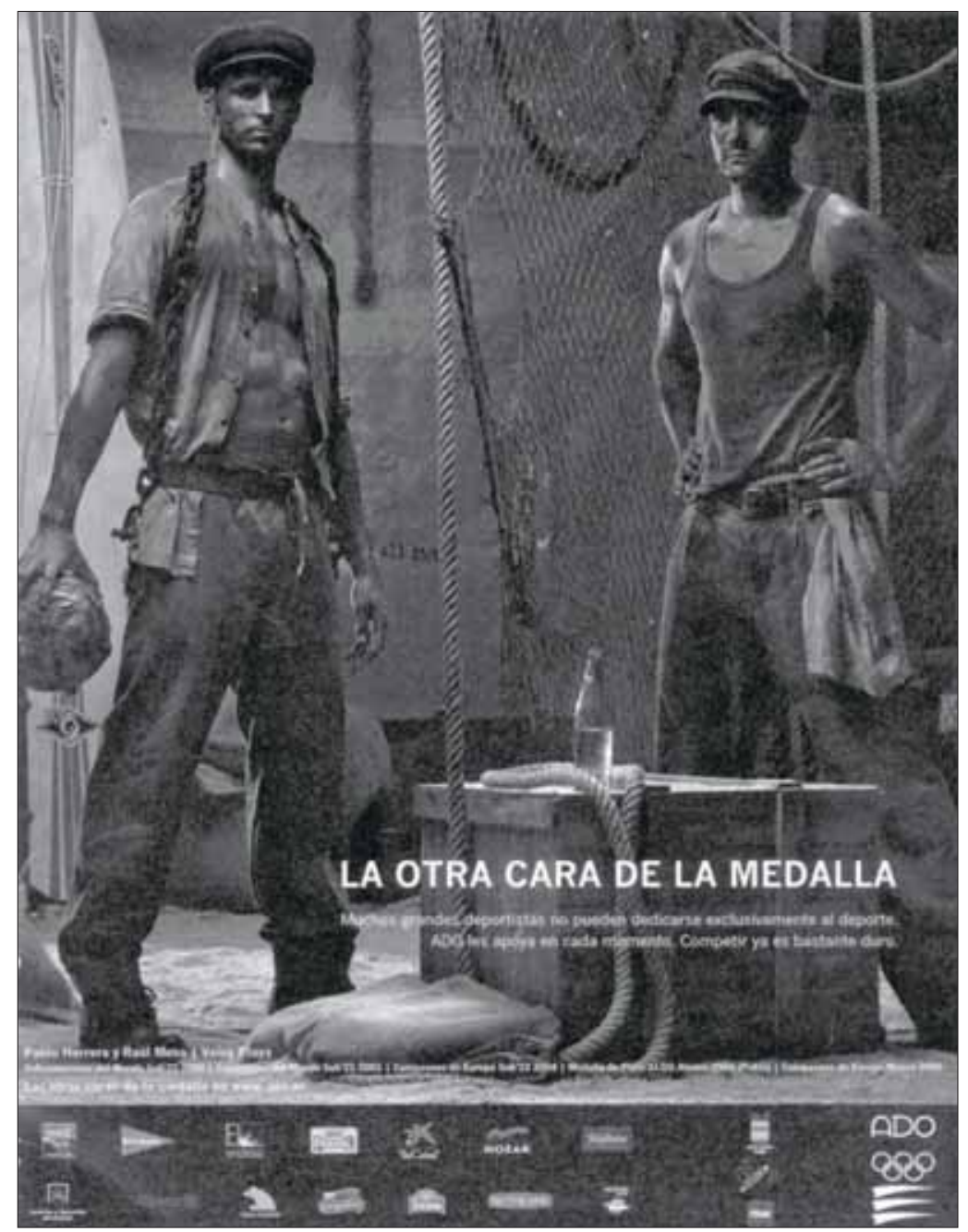

Fig. 15. El País Semanal. 2008

También la publicidad necesita de esos mismos héroes, porque casi no hay ningún otro reducto del que hoy puedan extraerse tan fabulosos comunicadores. Las guerras ya no son épicas, no fabrican héroes, sólo muertos. Nadal, Gasol, Messi, 
Ronaldo, son los nuevos ídolos, los nuevos semidioses, en parte reales y, en una parte mayor, fabricados por los propios medios de comunicación para servir a sus intereses. Por un lado, los medios fabrican esos héroes, no parte de la clase trabajadora sino de una nueva aristocracia, pero en una segunda fase los emplea publicitariamente para sus fines, los rentabiliza. En este sentido, periodismo y publicidad se complementan a la perfección, demostrando una vez más la debilidad de la línea que los separa. No sólo se necesitan mutuamente, en realidad colaboran activamente para conformar un entorno mítico, por no decir ideológico, del que pueden extraer rentabilidad. Retransmisiones, películas, documentales, entrevistas, reportajes, contribuyen a la mitificación de los deportistas que luego son empleados por sus anunciantes.

Mucha de la pasión actual por el deporte se debe indudablemente a los éxitos de nuestros deportistas en áreas como el fútbol, el tenis, el baloncesto o los deportes de velocidad. Porque, y ésta es una más de las ventajas de esta actividad sobre otras contemporáneas, el deporte nos ofrece esos héroes que toda sociedad parece necesitar para su pervivencia. Los deportistas, aún sin ser de ello conscientes, contribuyen a la conformación de una ideología en la medida en la que forman parte del entramado sociocomunicativo.

Luego está el mito, la leyenda que debe siempre acompañarles. En un anuncio se cuenta la siguiente historia: "Se crió en los bajos fondos. Maduró en los ambientes más lúgubres. Pero consiguió triunfar en la vida. // Si está pensando en un futbolista, se equivoca". El producto es un vino, pero el hecho es que como dice el mensaje "Detrás de los grandes triunfadores suele existir un origen de lo más humilde". Eso conviene a los héroes porque así obtienen una identificación mucho mayor con su público, resultan todavía más heroicos en su lucha contra las adversidades de la vida, en su búsqueda de la realización y el triunfo.

Pero además de héroes, el deporte, como antaño la religión, proporciona mártires. Cuando un atleta muere en un supremo esfuerzo (como ocurrió recientemente con un futbolista del Sevilla) un sentimiento de tragedia inunda la sociedad. Es el elemento patético del deporte, su derrota ante la naturaleza no lo destruye, no le hace fracasar, lo eleva a los altares. La efigie del mártir resucita en forma de icono en las camisetas de los hinchas, en las pancartas, en los mensajes del club. Se vuelve objeto de veneración y marca de la casa.

Estas tragedias, que son más habituales en unos que en otros deportes, demuestran la presencia en todos ellos de otro ingrediente básico. A la belleza, en los cuerpos y en los gestos, y al empleo de la tecnología (uno de nuestros fetiches contemporáneos) en los calzados, tejidos y equipamiento del deporte, se une el valor. El coraje de llevar el cuerpo al límite, el del enfrentamiento físico, el de conducir una máquina a velocidades de vértigo, el de salir a un escenario con setenta u ochenta mil espectadores. No sólo hace falta resistencia física, hace falta sobre todo fuerza mental. 
Belleza y coraje son por supuesto dos elementos cardinales de la actividad deportiva que atraen a los publicitarios. Pero no todo es físico en el deporte, también está toda esa parte técnica e imaginativa: las estrategias (un término algo tan querido también por los publicitarios), las jugadas "de pizarra", los movimientos en el campo, la habilidad, el ingenio, la capacidad de improvisación.

Pero la simbiosis entre deporte y comercio no se detiene en el uso de unos símbolos o en el empleo de unos soportes. La estructura integrante de la técnica deportiva sirve de paradigma, la competencia en el mercado es vista a la manera de las competiciones, la gestión empresarial se inspira en las categorías deportivas. Las reglas de funcionamiento, la especialización de las funciones (el lateral, el medio centro, el extremo, etc. en el fútbol), la racionalización, la organización profesional (asociaciones, clubes,...), la épica del esfuerzo, la recompensa del éxito. Todos esos rasgos y maniobras ofrecen un modelo de eficacia y rendimiento.

A la publicidad, el deporte le ofrece todo un repertorio de relatos, héroes, mitos y símbolos, capaces de resolver problemas de identidad personal o social; la lucha ancestral entre buenos y malos (entre el bien y el mal), más una serie de rituales, ceremonias y celebraciones. Se lo vincula, en principio, a aquellos elementos más próximos al espectador: la televisión, la cerveza, los amigos, la tertulia, la familia, el compañerismo, la comida para compartir, los refrescos, etc. Gracias a la televisión, y luego a Internet, el deporte se ha convertido en algo mucho más grande de lo que fue nunca: una celebración universal, una ceremonia global.

Pero todavía más, en un paso siguiente el deporte se vuelve publicidad, los clubes deportivos se transforman en marcas, los propios atletas se convierten en marcas, y eso quiere decir que deben formar parte del entramado seductor, que deben ser tan glamurosos, encantadores, políticamente correctos, fascinadores y persuasivos como corresponde a un engranaje publicitario. Convertidos en marcas genéricas, deportistas y clubes, lanzan, bajo su paraguas simbólico, toda clase de objetos de consumo: ropa, perfumes, complementos, relojes, calzado. Ya no es el viejo argumento persuasivo del testimonial: "Yo lo uso. Úsalo tú también". Ahora es "Yo soy esto. Tú también puedes serlo". El consumidor no imita simplemente los supuestos comportamientos de consumo de su héroe, se reviste de él, forma parte de él, se vuelve él.

En una época de desencantos políticos, de escepticismo crónico, de desconfianza ideológica, de fin de las certidumbres, el deporte surge como una tabla salvadora que sólo pide a cambio un poco de pasión. Hay algo melancólico en ello; en otros tiempos los jóvenes tenían otras cosas en qué pensar, no sólo más trascendentes, incluso más apasionantes que el deporte: la lucha política, los ideales, las creencias religiosas, cambiar el mundo. Probablemente los jóvenes de hoy son más sabios, y por lo tanto más recelosos. Lo cierto es que nunca ha existido mayor número de seguidores, más pasión concentrada, más fervor que el que existe hoy hacia el deporte. El deporte hace las veces de la identidad, y la gente se define por su condición de hincha de un club o de seguidor de un deportista.

En cierta forma la publicidad desaparece, en estas acciones, en beneficio de un término más amplio y más versátil como es el de comunicación. Aunque, por otro lado, es también el triunfo de la "forma publicitaria" (expresiva y seductora, tolerante 
y dúctil) sobre otras formas rígidas, informativas, didácticas, doctas, disciplinadas. Todo se ha vuelto forma publicitaria: el arte, las relaciones humanas, el entorno urbanístico, la moda, el paisajismo, la diversión, la cultura y, por supuesto, el deporte. Todo se vuelve marca, las empresas y las organizaciones, los clubes deportivos, los artistas y los atletas, los partidos políticos porque, como señala Baudrillard, la marca es "la única idea-fuerza grande y verdadera de esta sociedad competitiva" (Budrillard: 1989: 6). No es pues una muerte, sino una transfiguración por la que lo social tiende a confundirse con lo publicitario.

\section{Bibliografía}

BAUDRILLARD, Jean. (1989) "Publicidad absoluta, publicidad cero" en Revista de Occidente $\mathrm{n}^{\circ}$ 92. Enero, pp. 5-16. Madrid.

BRAVO, J. et al. (1994) 50 años de seducción. Madrid. Vogue.

CANSINOS-ASSÉNS, R. (1982) La novela de un literato. Madrid. Alianza.

DURRY, Jean. (1988) Le sport a l'affiche. Paris. Höebeke.

EGUIZÁBAL, R. (2002) Memoria de la seducción. Carteles del siglo XIX en la Biblioteca Nacional. Madrid. Biblioteca Nacional.

(2009) Industrias de la conciencia. Una historia social de la publicidad en España. Barcelona. Península.

FIGUEROA, A. de (1942) 1894. La vida de un año. Madrid. Revista de Occidente.

GONZÁLEZ CALLEJA, E. (2008) "La esencia del deporte" en ABC Cultural. 19-072008, pp. 4-6.

HARRIS, M. (2004) Teorías sobre la cultura en la era posmoderna. Barcelona. Crítica.

LELIEUR, A.-C.; BACHOLET, R. (1989) Célébrités a l'afiche. 100 ans de personnages célèbres dans la publicité. Lausanne. Conti.

PANOFSKY, E. (1987) El significado de las artes visuales. Madrid. Alianza Forma.

RAVENTÓS, J. Mª (2000) Cien años de publicidad española. Barcelona. Mediterránea Books.

RIERA FERRÁN, A. (2005) Estrategias de comunicación publicitaria. El uso del deporte en la publicidad televisiva en España. Murcia. Universidad Católica San Antonio.

\section{El autor}

Raúl Eguizábal Maza es Catedrático de la Universidad Complutense y autor, entre otros, de los libros Historia de la Publicidad (Eresma, 1998: nueva edición Fragua, 2011); Fotografía publicitaria (Cátedra, 2001), Teoría de la publicidad (Cátedra, 2007); Industrias de la conciencia. Una historia social de la publicidad en España (Península, 2009); El estado del malestar: capitalismo tecnológico y poder sentimental (Península, 2011). 